\title{
PENGEMBANGAN BAHAN AJAR E-LKPD BERBASIS PENGERINGAN IKAN ASIN PADA MATERI SUHU DAN KALOR FISIKA SMA
}

\author{
${ }^{1)}$ Kiki Dwi Trisnani ${ }^{1)}$ Subiki ${ }^{1)}$ Sri Astutik \\ ${ }^{1)}$ Program Studi Pendidikan Fisika FKIP Universitas Jember E-mail: \\ kikidwitrisnani@gmail.com
}

\begin{abstract}
The research aimed to develop teaching materials that are sontextual local wisdom in order to attract student in learning. The teaching materials that will be developed in this research are e-LKPD based on drying salted fish on temperatured and heat materials. The research method used in this research in the ADDIE development model. The ADDIE development model has five stages, namely Analysis, Design, Development, Implementation and evaluation. The research steps are carried out in accordanse with the ADDIE satges. The results of the research conducted, namely at the analysis stage, it was found that the lack of use of alternative teaching materials such as e-LKPD made student less interested during the learning process. Teaching materials that contain observation activities are meeded to improve psychomotor skills in students so that in this study the e-LKPD was developed by containing a simple experiment on drying salted fish. Preparation or writing of e-LKPD materials using the $3 d$ pageflip application. This applicatin has the adavantage of complete features that make the $3 d$ effect look real. This $3 d$ pageflip appication requires a number of computer devices to use and the installation process is quite long. The constraints of this research are that the computer equipment owned by the researcher does not support the installation of the $3 d$ pagefip application, the limited time of the study, and the limitation of the researcher in usng the $3 d$ pageflip application so that the research is only carried out until the design stage.
\end{abstract}

Key word: E-LKPD, Temperature and heat, Drying salted fish

\section{PENDAHULUAN}

Fisika adalah cabang ilmu pengetahuan alam yang memiliki hakikat serupa dengan sains. Sains dapat dikatakan sebagai ilmu ynag diperoleh dari kegiatan penelitian oleh ilmuwan selama berabadabad. Fiika dalam kajian alam mempelajari mengenai berbagai fenomena alam berupa materi pada lingkup waktu dan ruang. Ilmuwan atau fisikawan mempelajari mengenai perilaku maupun sifat materi pada fisika partikel yang terbentuk dari partikel submikroskopis sampai materi alam semesta sebagai satu kesatuan kosmos (Giancoli, 2014).

Pembelajaran fisika merupakan aktivitas belajar mengajar yang berhubungan dengan fenomena alam. Fisika membahas mengenai gejala-gejala alam secara runtut yang didasarkan pada penelitan telah dilakukan oleh fisikawan (Samatowa, 2011). Pembelajaran fisika memiliki tujuan untuk membekali peserta didik dengan pengetahuan, pemahaman, dan kemampuan untuk mengembangkan ilmu pengetahuan 
dan teknologi (Priandono et al., 2012). Penelitian yang dilakukan Subakti et al. (2021), didapati hasil bahwa pembelajaran membutuhkan bahan ajar yang dapat dengan mudah digunakan dimana saja. Selain itu bahan ajar yang menghemat biaya operasional dan yang paling penting dapat membuat peserta aktif dalam pembelajaran diperlukan dalam pembelajaran. Bahan ajar adalah media pembelajaran yang didalamnya memuat konsep materi yang dipelajari, batasan-batasan pembelajaran, metode serta langkah untuk melakukan evaluasi. Tujuan pembelajaran merupakan ketercapain kompetensi serta subkompetensi dengan segala kompleksitasnya (Widodo, 2008). Bahan ajar sangat berkontribusi pada kegiatan pembelajaran, bahan ajar dapat menjadi penentu keberhasilan kegiatan pembelajaran yang berhubungan dengan tercapainya tujuan pembelajaran yang sedang dilakukan (Hamalik, 2003).

Bahan ajar adalah media pembelajaran yang didalamnya memuat konsep materi yang dipelajari, batasanbatasan pembelajaran, metode serta langkah untuk melakukan evaluasi. Tujuan pembelajaran merupakan ketercapain kompetensi serta subkompetensi dengan segala kompleksitasnya (Widodo, 2008). Bahan ajar sangat berkontribusi pada kegiatan pembelajaran, bahan ajar dapat menjadi penentu keberhasilan kegiatan pembelajaran yang berhubungan dengan tercapainya tujuan pembelajaran yang sedang dilakukan (Hamalik, 2003).

Pada abad ke-21 ini perkembangan teknologi dan informasi sangatlah pesat yang mendorong semua bidang untuk menguasai teknolosi tidak terkecuali bidang pendidikan. Penggunaan bahan ajar yang berbasis teknologi perlu dikuasi oleh guru dan peserta didik. Perkembangan teknologi ini memiliki pengaruh pada kemajuan inovasi bahan ajar yang digunakan dalam pembelajaran contohnya bahan ajar yang berbentuk elektronik seperti elektronik Lembar Kerja Peserta Didik (e-LKPD) yang didalamnya sudah memuat materi, soal latihan, video yang dapat menarik dan memudahkan peserta didik selama belajar. Bahan ajar elektronik dibutuhkan untuk memudahkan peserta didik pada masa pandemi, dimana pembelajaran dilakukan dengan jarak jauh untuk menghindari adanya penyebaran virus. Akan tetapi penggunaan bahan ajar elektronik disekolah-sekolah jarang ditemui terutama disekolah-sekolah yang ada didesa. Penggunaan bahan ajar cetak masih mendominasi dalam pembelajaran. Terutama pada pembelajaran fisika, guru masih menggunakan bahan ajar yang biasa dan tidak menarik bagi peserta didik sehingga peserta didik susah dalam memahami materi. Selain itu penggunaan bahan ajar yang dikaitkan dengan konteksual fenomena-fenomena yang terjadi disekitar peserta didik dibutuhkan guna menarik minat belajar peserta didik.

Menurut Ibrahim

(2015), pembelajaran fisika akan selalu berkaitan erat dengan lingkungan, sehingga akan lebih baik apabila dalam pembelajaran fisika memanfaatkan bahan ajar yang memiliki kaitan erat dengan lingkungan dan kebutuhan peserta didik. Penelitian yang telah dilakukan Situmorang (2016), mengatakan bahwa keberadaan objek pembelajaran yang berorientasi pada kearifan lokal diharapkan dapat mengajak peserta didik untuk mengungkapkan fenomena, fakta-fakta serta diharapkan melalui pemahaman konsep dapat membuat peserta didik lebih mengenal daerah masingmasing. Kearifan lokal atau local wisdom adalah kebudayaan masyarakat daerah yang dipengaruhi oleh faktor geografis. Local wisdom juga merupakan pegangan hidup masyarakat lokal yang telah diturunkan dari masa lalu. Penelitian yang akan dilakukan peneliti mengangkat local wisdom pengeringan ikan asin yang berada di 
Kecamatan Muncar. Pengembangan bahan ajar yang akan dilakukan mengenai pengaitan antara materi Suhu dan Kalor dengan kearifan lokal ikan asin.

Penelitian yang akan dilakukan peneliti mengangkat kearifan lokal ikan asin yang berada di Kecamatan Muncar. Pengembangan bahan ajar yang akan dilakukan mengenai pengaitan antara materi Suhu dan Kalor dengan kearifan lokal ikan asin.

\section{METODE}

Jenis penelitian yang digunakan pada penelitian pengembangan ADDIE (Sugiyono, 2010). Penelitian ini merupakan penelitian dan pengembangan (Research and Development) untuk menciptakan sebuah produk yang baru dan menguji keefektifan dari produk tersebut. Menurut Sugiyono (2015), penelitian pengembangan ADDIE terdiri dari lima tahapan yakni Analysis, Design, Development, Implementation, and Evaluation. Berikut tahapan-tahapan penelitian pengembangan ADDIE menurut Sugiyono (2015): (1) tahap analysis ini dilakukan analisis kebutuhan dan permasalahan; (2) tahap design yakni melakukan perumusan tujuan pembelajran, menentukan materi dan melakukan penyusunan bahan ajar; (3) tahap development in dilakukan penulisan materi pada bahan ajar; (4) tahap implementation yakni dilakukan penggunaan produk yang berupa bahan ajar; dan (5) tahap evaluation yakni dilakukan evaluasi penggunaan eLKPD.

Penelitian ini dilaksanakan di tempat industri ikan asin yang berada dipelabuhan yang ada di Kecamatan Muncar. Observasi dan wawancara dilakukan di MAN 3 Banyuwangi yang beralamatkan di Jl. Raya Srono, Sukomaju, Kecamatan Srono, Kabupaten Banyuwangi, Jawa Timur 68471. Waktu penelitian dilakukan pada semester genap tahun ajaran 2020/2021.
Penelitian ini menggunakan teknik analisis data berupa wawancara dan validasi. Wawancara dilakukan untuk mengetahui kebutuhan dan permasalahan peserta didik selama pembelajaran. Selain itu juga dilakukan wawancara kepada pemilik industri ikan asin untuk menggali informasi mengenai proses pembuatan ikan asin yang berada di Kecamatan Muncar.Validasi eLKPD berbasis Local Wisdom di Kecamatan Muncar dilakukan dilakukan oleh dua validator yakni dosen pendidikan fisika dan satu validator guru fisika. Validasi ini bertujuan untuk mengetahui kelayakan dan kritik saran mengenai kekurangankekurangan e-LKPD yang perlu diperbaiki. Instrumen validasi ini menggunakan lembar validator yang berisi aspek nilai dan deskripsi. Data yang diperoleh dari hasil uji validasi ahli kemudian dianalisis untuk mengetahui tingkat kevalidan e-LKPD, untuk menghitung persentase kevalidan eLKPD dapat menggunakan persamaan berikut ini:

$$
\mathrm{P}=\frac{\Sigma \mathrm{y}}{\Sigma \mathrm{yi}} \times 100 \%
$$

Keterangan:

$\mathrm{P} \quad=$ Persentase validasi

$\Sigma y \quad=$ Jumlah nilai validasi ahli

Syi = Nilai maksimal validasi

Validasi pada penelitian ini menggunakan tiga validator, untuk menentukan nilai akhir atau rata-rata dari hasil validasi menggunakan rumus sebagai berikut:

$$
P_{\text {total }}=\frac{P_{1}+P_{2}+P_{3}}{3}
$$

Keterangan:

$\mathrm{P}_{\text {total }}=$ Nilai akhir atau rata-rata validasi

$\mathrm{P}_{1} \quad=$ Nilai validator 1

$\mathrm{P}_{2} \quad=$ Nilai validator 2

$\mathrm{P}_{3} \quad$ = Nilai validator 3 (Guru)

Menurut Sudaryono, (2011), LKPD dikatakan valid apabila hasil uji validitas memperoleh nilai $\geq 61 \%-100 \%$. persentase tingkat kevalidan dapat dilihat dalam Tabel 1 berikut. 
Tabel 1. Konversi Persentase Validasi

\begin{tabular}{ll}
\hline Persentase & Interpretasi \\
\hline $0 \%-20 \%$ & Tidak Valid \\
$21 \%-40 \%$ & Kurang Valid \\
$41 \%-60 \%$ & Cukup Valid \\
$61 \%-80 \%$ & Valid \\
$81 \%-100 \%$ & Sangat Valid \\
\hline
\end{tabular}

\section{HASIL DAN PEMBAHASAN}

Pengembangan elektronik Lembar Kerja Peserta Didik (e-LKPD) berbasis pengeringan ikan asin dilakukan dengan menggunakan model pengembanga ADDIE. Model pengembangan ADDIE memiliki lima tahapan pengembangan yakni Analysis, Desain, Development, Implementation, and Evaluation. Pengembangan yang dilakukan pada penelitian ini sampai tahap implementasi dikarenakan pada penelitian ini bertujuan untuk mengembangkan dan mengetahui kevalidan e-LKPD yang telah dikembangkan.

Prosedur Pengembangan e-LKPD meliputi tahapan:

(1) Analysis (Analisis). Tahap analisis ini mengenai permasalahan dan kebutuhan yang dilakukan dengan cara observasi dan wawancara. Hasil dari analisis yang telah dilakukan yakni menurut pembelajaran yang dilakukan di ruang kelas kurang melibatkan peserta didik selama proses pembelajaran. Bahan ajar yang digunakan guru selama proses pembelajaran hanya menggunakan buku cetak dan kurangnya penggunaan alternatif bahan ajar seperti e-LKPD sehingga membuat peserta didik kurang tertarik selama proses pembelajaran. LKPD yang memuat kegiatan pengamatan diperlukan dalam proses pembelajaran untuk meningkatkan skill psikomotorik pada peserta didik. Fisika yang masih diajarkan dengan metode konvensional atau berorientasi kepada guru membuat peserta didik memiliki kecenderungan menerima tanpa memahami makna dari yang telah disampaikan oleh guru. Selain itu pembelajaran daring yang dikarenakan adanya pandemi juga menjadi penghambat pembelajaran. Selama pembelajaran daring guru hanya memberikan soal-soal latihan kepada peserta didik yang menyebabkan peserta didik tidak memahami materi yang diajarkan secara menyeluruh dan cenderung menghafal rumus-rumus yang digunakan selama proses pengerjaan soal latihan.

(2) Design (Desain).

Tahap desain pada penelitian ini yakni dilakukan dengan perumusan tujuan pembelajran, materi yang akan digunakan dan penyusunan desain e-LKPD. Tujuan pembelajaran e-LKPD yang akan dikembangkan yaitu: (1) menganalisis pengarih kalor dan perpindahan kalor pada proses pengeringan ikan asin; (2) mensejajarkan local wisdom dan pengetahuan ilmiah dengan kajian pengeringan ikan asin dengan konsep suhu dan kalor; (3) menunjukkan sikap ilmiah (rasa ingin tahu, objektif, jujur, tetliti, cermat, tekun, hati-hati, bertanggung jawab, terbuka, kritis, kreatif, inovatif, dan peka terhadap local wisdom yang ada dilingkungannya); (4) menunjukkan sikap kritis dan kreatif dalam menganalisis penerapan konsep dalam kehidupan seharihari.

Materi yang akan digunakan pada eLKPD yang dikembangkan yakni suhu dan kalor dengan kontekstual pengeringan ikan asin. e-LKPD yang akan dikembangkan memuat percobaan sederhana mengenai pengeringan ikan asin. Percobaan sederhana akan dilakukan dengan dua macam perlakuan yakni perlakuan dengan besek bambu dan perlakuan dengan nampan seng atau nampan yang terbuat dari bahan konduktor. Percobaan ini dilakukan sesuai dengan pembuatan ikan asin yang ada di Kecamatan Muncar. Proses pembuatan ikan asin yang dilakukan yakni pembersihan 
ikan, penggaraman ikan, dan penjemuran ikan.

Desain awal dari elektronik Lembar Kerja Peserta Didik (e-LKPD) pada penelitian ini didesain dan dibuat dengan menggunakan Microsoft Word. Desain eLKPD dimulai dengan penentuan konsep, judul atau cover, penentuan isi dari e-LKPD. Judul atau cover dari e-LKPD didesain dengan menggunakan aplikasi Canva sebagaimana ditunjukkan pada Gambar 1 berikut.

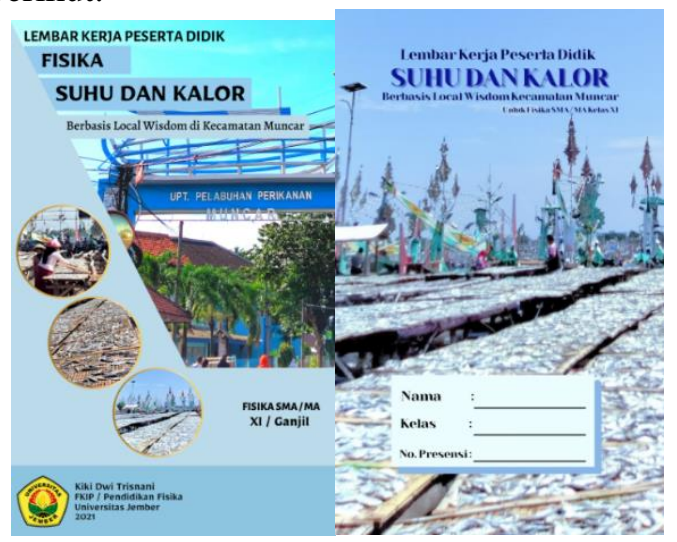

Gambar 1. Judul atau Cover e-LKPD

Sumber: dokumentasi pribadi

Pembuatan Cover e-LKPD ini dilakukan dengan mengumpulkan foto-foto yang berkaitan dengan Local Wisdom di Kecamatan Muncar terlebih dahulu. Pembuatan Header dan Footer menggunakan Microsoft Word. Berikut desain dari Header dan Footer untuk eLKPD. Sebagaimana ditunjukkan pada Gambar 2 berikut.

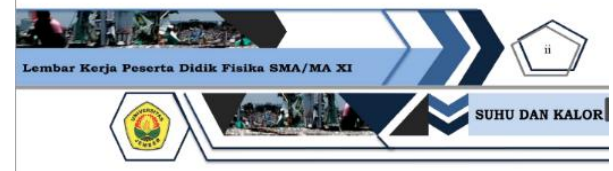

Gambar 2. Header dan Footer e-LKPD Sumber: dokumentasi pribadi

\section{(3) Development (Pengembangan)}

Aplikasi yang akan digunakan untuk menyusun e-LKPD berbasis pengeringan ikan asin adalah 3d pageflip. 3d pageflip merupakan aplikasi yang dapat digunakan untuk mengubah e-LKPD yang masih dalam bentuk pdf menjadi e-LKPD yang memiliki efek 3d. 3d pageflip memiliki fitur yang lengkap sehingga efek yang dihasilkan pada e-LKPD akan terlihat sangat nyata. Selain memiliki berbagai kelebihan seperti yang telah disebutkan, aplikasi 3d pageflip juga memiliki kekurangan diantaranya yakni aplikasi ini memerlukan jumlah perangkat komputer dalam pengoperasiannya, proses instalasi yang cukup lama, serta apabila mengubah tulisan yang berasal dari buku harus menggunakan ukuran font lebih besar. Kendala yang dialami peneliti dalam penelitian ini yakni perangkat komputer yang dimiliki peneliti tidak mendukung untuk instalasi aplikasi 3d pageflip, keterbatasan waktu penelitian, dan keterbatasan peneliti dalam penggunaan aplikasi 3d pageflip ini, sehingga penelitian hanya dapat dilakukan sampai tahap design.

(4) Implementation (Implementasi)

Tahap implementasi pada penelitian ini yakni tahap penggunaan e-LKPD. Pada tahap ini tidak dapat dilakukan dikarenakan e-LKPD yang dihasilkan pada penelitian ini masih rancangan dan memerlukan penelitian lebih lanjut.

(5) Evaluation (Evaluasi)

Tahap evaluasi pada penelitian ini bertujuan untuk mengetahui kelayakan dari e-LKPD yang telah dikembangkan. Tahap ini tidak dapat dilakukan dikarenakan tahap pengembangan e-LKPD yang dilakukan hanya sampai tahap Design.

Penelitian ini difokuskan pada pengembangan bahan ajar interaktif $3 d$ yang berbasis pengeringan ikan asin yang berupa elektronik Lembar Kerja Peserta Didik (eLKPD). Penggunaan e-LKPD berbasis pengeringan ikan asin ini diupayakan untuk mengenalkan peserta didik kepada kebudayaan dan kebiasaan yang ada di daerahnya. Bahan ajar pada e-LKPD 
berbasis pengeringan ikan asin Kecamatan Muncar menekankan pada percobaan yang berkaitan dengan pengukuran suhu dan massa ikan sebelum dan sesudah mengalami proses pengeringan di bawah terik sinar matahari serta perhitungan kalor yang diperlukan selama proses pengeringan dan analisis peserta didik mengenai pengeringan dengan perlakuan dengan menggunakan besek bambu dan perlakuan dengan menggunakan alas seng. Seng sendiri memiliki karakteristik fisik yang keras dan rapuh pada suhu tertentu, mampu menghantarkan listrik dan panas dengan baik. Sedangkan karakteristik bambu sendiri secara fisik bambu memiliki karakteristik yang rapuh dan merupakan penghantar panas yang buruk dikarenakan tergolong benda berpori.

Masyarakat Muncar dalam proses pengeringan menggunakan besek bambu dikarenakan harga yang relatif murah dan mudah ditemukan. Selain itu, bambu dapat menghasilkan ikan asin yang memiliki kekeringan yang sempurna meskipun bambu tergolong pada material yang tidak menghantarkan panas dengan baik akan tetapi selama proses pengeringan ikan bambu memiliki panas yang stabil dibandingkan dengan alas yang terbuat dari material seng dan sejenisnya. Pengeringan yang dilakukan dengan besek bambu memiliki hasil ikan yang kering luar dan dalam sedangkan pengeringan dengan alas seng memiliki hasil pengeringan ikan hanya kering pada bagian luar atau kulitnya saja.

e-LKPD yang dikembangkan pada penelitian ini berupa elektronik sehingga memudahkan peserta didik dalam mengaksesnya. E-LKPD dikembangkan dengan aplikasi 3d pageflip, aplikasi ini memiliki berbagai fitur yang dapat menjadikan rancangan e-LKPD yang awalnya dalam bentuk pdf maupun word dapat diubah ke dalam bentuk $3 \mathrm{~d}$. $3 \mathrm{~d}$ pageflip selain memiliki kelebihan aplikasi ini juga memiliki kekurangan. Dimana dalam penggunaannya diperlukan perangkat komputer yang banyak selain itu proses instalasi aplikasi pada laptop juga memerlukan waktu yang lama. Kendala yang dialami peneliti dalam penelitian ini yakni perangkat komputer yang tidak mendukung untuk instalasi aplikasi, keterbatasan waktu penelitian serta keterbatasan peneliti dalam penggunaan aplikasi 3d pageflip sehingga penelitian ini hanya sampai tahap design.

Rancangan e-LKPD berbasis pengeringan ikan asin ini memuat materi suhu dan kalor, Local Wisdom pengeringan ikan asin Kecamatan Muncar, percobaan suhu dan kalor, serta evaluasi yang berupa soal uji kompetensi. Materi yang dimuat pada e-LKPD ini disesuaikan dengan kompetensi inti dan indeks pencapaian kompetensi. Soal-soal uji kompetensi yang digunakan menggunakan soal-soal yang berada pada buku pelajaran fisika kelas XI materi suhu dan kalor dengan sedikit modifikasi sesuai dengan Local Wisdom di Kecamatan Muncar. Penelitian pengembangan e-LKPD ini menggunakan metode penelitian pengembangan ADDIE dengan tahapan Analysis, Design, Development, Implementation, and Evaluation. Penelitian pengembangan pada penelitian ini berakhir pada tahap Design.

\section{SIMPULAN DAN SARAN}

Berdasarkan data penelitian yang telah diperoleh dari Elektronik Lembar Kerja Peserta Didik (E-LKPD) berbasis pengeringan ikan asin Kecamatan Muncar yang telah diuraikan sebelumnya dapat ditarik kesimpulan bahwa rancangan eLKPD yang telah disusun masih perlu dilanjutkan pada tahap pengubahan e-LKPD dengan aplikasi $3 \mathrm{~d}$ pageflip. Rancangan yang telah dihasilkan perlu diteliti lebih lanjut untuk mengetahui kelayakan 
berdasarkan uji coba lapang. Elektronik Lembar Kerja Peserta Didik (e-LKPD) berbasis pengeringan ikan asin di Kecamatan Muncar ini masih dalam bentuk rancangan sehingga masih diperlukan perbaikan dan pengembangan yang lebih lanjut oleh peneliti selanjutnya sampai pada tahap implementasi kepada peserta didik. Penelitian lanjutan diperlukan spesifikasi laptop Windows XP, Vista, Windows 7, 8 dan 10 dengan kapasitas memori 2048MB RAM. Selain itu peneliti harus memiliki kemampuan dalam penggunaan aplikasi untuk mencipatakan ilustrasi yang menarik serta waktu penelitian yang lebih lama.

\section{DAFTAR PUSTAKA}

Giancoli. (2014). Fisika: Prinsip dan Aplikasi. Jakarta: erlangga.

Hamalik, O. (2003). Perencanaan Pengajaran Berdasarkan Pendekatan Sistem. Jakarta: bumi aksara.

Ibrahim. (2015). Metodologi Penelitian Kualitatif. Bandung: alfabeta.

Priandono, F. E., Astutik, S., \& Wahyuni, S. (2012). Pengembangan Media AudioVisual Berbasis Kontekstual Dalam Pembelajaran Fisika di SMA. Jurnal Pembelajaran Fisika, 1(3), 247-253.

Samatowa, U. (2011). Pembelajaran IPA di Sekolah Dasar. Jakarta: Indeks.

Situmorang, M. , J. I. S. , P. L. A. (2016). Pengembangan Bahan Ajar Inovatif Berbasis Multimedia Untuk Meningkatkan Hasil Belajar Mahasiswa pada Pembelajaran PH Larutan. Jurnal Pendidikan Kimia., 8(2), 112119. 